University of Nebraska - Lincoln

DigitalCommons@University of Nebraska - Lincoln

\title{
Effects of gamma-sterilization on the physico-chemical properties of natural sediments
}

T.L. Bank

Oak Ridge National Laboratory, tlbank@buffalo.edu

Ravi K. Kukkadapu

Pacific Northwest National Laboratory, ravi.kukkadapu@pnl.gov

A.S. Madden

Oak Ridge National Laboratory

M.A. Ginder-Vogel

Stanford University

M.E. Baldwin

Oak Ridge National Laboratory

See next page for additional authors

Follow this and additional works at: https://digitalcommons.unl.edu/usdoepub

Part of the Bioresource and Agricultural Engineering Commons

Bank, T.L.; Kukkadapu, Ravi K.; Madden, A.S.; Ginder-Vogel, M.A.; Baldwin, M.E.; and Jardine, P.M., "Effects of gamma-sterilization on the physico-chemical properties of natural sediments" (2008). US Department of Energy Publications. 144.

https://digitalcommons.unl.edu/usdoepub/144

This Article is brought to you for free and open access by the U.S. Department of Energy at DigitalCommons@University of Nebraska - Lincoln. It has been accepted for inclusion in US Department of Energy Publications by an authorized administrator of DigitalCommons@University of Nebraska - Lincoln. 


\section{Authors}

T.L. Bank, Ravi K. Kukkadapu, A.S. Madden, M.A. Ginder-Vogel, M.E. Baldwin, and P.M. Jardine 


\title{
Effects of gamma-sterilization on the physico-chemical properties of natural sediments
}

\author{
T.L. Bank ${ }^{\text {a, } *}$, R.K. Kukkadapu ${ }^{\text {b }}$, A.S. Madden ${ }^{\text {a,1 }}$, M.A. Ginder-Vogel ${ }^{\text {c,2 }}$, M.E. Baldwin ${ }^{\text {d }}$, P.M. Jardine ${ }^{\text {a }}$ \\ a Environmental Sciences Division, Oak Ridge National Laboratory, Oak Ridge, TN 37831, United States \\ b Pacific Northwest National Laboratory, Richland, WA, 99352, United States \\ c Department of Geological and Environmental Sciences, Stanford University, Stanford, CA, 94305, United States \\ ${ }^{\mathrm{d}}$ Nuclear Science and Technology Division, Oak Ridge National Laboratory, Oak Ridge, TN 37831, United States
}

\section{A R T I C L E I N F O}

\section{Article history:}

Received 22 August 2007

Received in revised form 26 December 2007 Accepted 9 January 2008

Editor: J. Fein

\section{Keywords:}

Gamma-irradiation

Soil sterilization

Redox

Mössbauer

\begin{abstract}
A B S T R A C T
Batch $\mathrm{U}(\mathrm{VI})$ sorption/reduction experiments were completed on sterilized and non-sterilized sediment samples to elucidate biological and geochemical reduction mechanisms. Results from X-ray absorption nearedge structure (XANES) spectroscopy revealed that $\gamma$-sterilized sediments were actually better sorbents of $\mathrm{U}(\mathrm{VI})$, despite the absence of any measurable biological activity. These results indicate that $\gamma$-irradiation induced significant physico-chemical changes in the sediment which is contrary to numerous other studies identifying $\gamma$-sterilization as an effective and minimally invasive technique.

To identify the extent and method of alteration of the soil as a result of $\gamma$-sterilization, untreated soil samples, physically separated size fractions, and chemically extracted fractions of the soil were analyzed pre- and post-sterilization. The effects of sterilization on mineralogy, $\mathrm{pH}$, natural organic matter (NOM), cation exchange capacity (CEC), and iron oxidation state were determined. Results indicated that major mineralogy of the clay and whole sediment samples was unchanged. Sediment pH decreased only slightly with $\gamma$-irradiation; however, irradiation produced a significant decrease in CEC of the untreated sediments and affected both the organic and inorganic fractions. Mössbauer spectra of non-sterile and $\gamma$-sterilized sediments measured more reduced iron present in $\gamma$-sterilized sediments compared to non-sterile samples. Our results suggest that sterilization by $\gamma$-irradiation induced iron reduction that may have increased the sorption and/or reduction of $\mathrm{U}(\mathrm{VI})$ onto these sediments. However, Mössbauer and batch sorption data are somewhat contradictory, the former indicates that the iron oxide or iron hydroxide minerals are more significantly reduced while the later indicates that reduced clay minerals account for greater sorption of $\mathrm{U}(\mathrm{VI})$.
\end{abstract}

(c) 2008 Elsevier B.V. All rights reserved.

\section{Introduction}

Sterile laboratory methods are needed to elucidate biological and abiological processes that occur in sedimentary systems. Particularly in the field of remediation, more detail is needed on the rate and extent of biological and abiological geochemical reactions that occur indigenously and can be stimulated. To achieve this, a non-invasive method for soil sterilization is needed. Ideally, sterilization should cause no measurable changes in the physical or chemical properties of the soil while completely eliminating all viable organisms. However,

* Corresponding author. Current address: 876 Natural Sciences Complex, Department of Geology, University at Buffalo, Buffalo, NY, 14260-3050, United States. Tel.: +1 716645 6800x3985; fax: +1 7166453999 .

E-mail address: tlbank@buffalo.edu (T.L. Bank).

1 Current address: School of Geology and Geophysics, University of Oklahoma, Norman, OK, 73019.

2 Current address: Department of Plant and Soil Sciences, University of Delaware, Newark, DE, 19716. with the possible exception of mercuric chloride, all known sterilization methods cause some secondary effect on the soil (Wolf et al., 1989; Lotrario et al., 1995; Trevors, 1996; McNamara et al., 2003). While poisons and fumigants are highly effective sterilizers, they leave behind toxic residues which may cause contamination and lead to difficult disposal (Trevors, 1996; McNamara et al., 2003). Autoclaving, which is the more commonly used method of sterilization, kills cells by raising temperatures to $121^{\circ} \mathrm{C}$ at $103.4 \mathrm{kPa}$. Although the efficiency of autoclaving is low, it is significantly improved by repeated autoclaving two or three times. Unfortunately, repetition results in more significant structural soil damage (Wolf et al., 1989). Autoclaving can cause aggregation of clay particles which leads to a decrease in soil surface area and significant changes in the adsorption of organic compounds (Lotrario et al., 1995; Trevors, 1996). Additionally, the chemical affects of triplicate autoclaving are significant. Extractable Mn levels were reported to increase by an average of $500 \%$ while extractable Fe decreased significantly in one study of the effects of sterilization on various soil types (Wolf et al., 1989). 
Though autoclaving tends to be more commonly used, some studies have found sterilization by exposure to $\gamma$-irradiation emitted by cobalt-60 to be less destructive and more effective (Bowen and Rovira, 1961; McLaren, 1969; Allen et al., 1999; ; Lotrario et al., 1995; Trevors, 1996; McNamara et al., 2003; Herbert et al., 2005). Small doses of $\gamma$-irradiation are capable of sterilizing large soil samples without increasing soil temperature or pressure. For determining abiotic reaction rates in mine tailings, $\gamma$-radiation was suggested as the most effective sterilization method (Herbert et al., 2005). Sterilization by $\gamma$-irradiation was recently popularized when it was suggested as a suitable technique for sterilization of Mars samples (Allen et al., 1999). Experiments showed that a dose of $30 \mathrm{Mrad}$ of $\gamma$ irradiation caused no measurable changes in isotopic signature, chemical composition, crystallographic structure, or homogenization temperatures of fluid inclusions in rocks and minerals analogous to those found on Mars. Recently, the use of $\gamma$-irradiation in studies of microbial respiration rates and geochemical reaction rates of natural soils has gained popularity (Golde et al., 1994; Apitz et al., 1999; Getenga et al., 2004; Herbert et al., 2005; Manning et al., 2006). However, descriptions of the effects of moderate doses of ionizing radiation on whole soils or even naturally occurring minerals remain incomplete.

The ionizing radiation produced by cobalt-60 generates radicals that are capable of cleaving carbon-carbon bonds thereby destroying cellular DNA and leaving cells non-viable (Tuominen et al., 1994; Trevors, 1996). At the low doses of irradiation required to kill cells in most soil types (<50 kGy (McNamara et al., 2003)), $\gamma$-sterilization causes minimal perturbations to the physical properties of soils (Wolf et al., 1989; Lotrario et al., 1995). Although some chemical alterations have been reported, the effects on bulk soils are minimal compared to other sterilizing methods (for a complete review see (McNamara et al., 2003)). At high doses of $\gamma$-irradiation (>50 kGy), however, changes in clay mineral chemistry and organic matter have been observed. These changes include reduction of trivalent iron to the divalent state (Gournis et al., 2001; Plotze et al., 2003), change in clay mineral solubility (Pushkareva et al., 2002), migration of lattice cations in smectites (Gournis et al., 2001), and reduction of dissolved organic concentrations (Bunzl and Schimmack, 1988; Kreller et al., 2005). One study of the effects of irradiation on five layered silicate minerals found structural properties remained unaltered while some minerals experienced a change in the oxidation state of iron (Negron et al., 2002).

In this study, experiments to elucidate biological and abiological $\mathrm{U}$ (VI) reduction were completed using $\gamma$-sterilized, autoclaved and nonsterile sediment samples. U(VI) sorption results suggested that sterilization by moderate doses of $\gamma$-irradiation induced chemical changes in certain fractions of these sediment samples that were not previously reported, specifically the iron oxides and iron hydroxide minerals. To understand the physico-chemical changes induced in natural sediments by $\gamma$-irradiation, major mineralogy, soil $\mathrm{pH}$, UV-Vis absorbance, cation exchange capacity (CEC), and the oxidation state of Fe were measured on non-sterile, autoclaved, and $\gamma$-irradiated soil samples, physically separated size fractions of the soil, and chemically treated sub-samples.

\section{Materials and methods}

\subsection{Sample collection}

Bulk soil samples were collected from an interbedded sequence of weathered shale and limestone at the Melton Branch Watershed on the Oak Ridge Reservation in eastern Tennessee. The shale has been extensively weathered to saprolite and the limestone has been completely weathered to massive clay lenses. Soils that exhibited the grey-green coloring typical of reducing conditions were removed from the transition zone located immediately above and below the water table. Soil samples were stored at $4{ }^{\circ} \mathrm{C}$ before processing. A complete description of the soil geochemistry and hydrodynamics is given in Jardine et al. (Jardine et al., 1988; Jardine et al., 2001).

\subsection{Soil sterilization and analysis}

To obtain a more homogenous representation of the complex sediment, soil samples were air-dried, large aggregates were crushed, and sediments sieved to less than $2 \mathrm{~mm}$ prior to all analyses. Selected sub-samples of the soil were also treated with $30 \% \mathrm{H}_{2} \mathrm{O}_{2}$ to remove and quantify the NOM content. Additional sub-samples of $\mathrm{H}_{2} \mathrm{O}_{2-}$ treated soils were treated with dithionite-citrate-bicarbonate (DCB) solution to remove and quantify the reducible Fe(III) content of the soil, predominantly as iron oxides (Jackson et al., 1986). In addition, sub-samples of soil were prepared for mineralogical analyses and the sand, silt, and clay fractions were separated by mechanical sieving and by centrifugation (Klute, 1986).

Untreated, $\mathrm{H}_{2} \mathrm{O}_{2}$-treated, and $\mathrm{H}_{2} \mathrm{O}_{2}$ plus DCB-treated soil samples were sterilized by either autoclave or $\gamma$-irradiation. Soils were steam sterilized three times in polypropylene Oak Ridge tubes at $121{ }^{\circ} \mathrm{C}$ for $20 \mathrm{~min}$. Soils were stored at room temperature for $24 \mathrm{~h}$ between each autoclave run. A J. L. Shepherd model $109{ }^{60} \mathrm{Co}$ irradiator was used to sterilize samples by $\gamma$-irradiation. Irradiated samples were contained in vented polypropylene tubes during sterilization and irreversible temperature labels (Omega Engineering Inc.) were used to record the maximum temperature reached during sterilization $\left(<40^{\circ} \mathrm{C}\right)$. Samples were sterilized for $40 \mathrm{~h}$ at a rate of $50 \mathrm{krad} / \mathrm{h}$ for a total $\gamma$-ray dosage of $20 \mathrm{kGy}$. The success rate of soil sterilization was measured by counting viable cells using the most probable number (MPN) technique before and after sterilization. Cells were enumerated aerobically in tryptic soy broth (TSB). MPNs were also completed on the sand and clay fractions of the soil separately.

To determine the effects of sterilization on the sediment samples, major mineralogy and clay mineralogy were identified by X-ray diffraction (XRD). The major mineralogy of the sand, silt and clay fractions was identified by XRD using a Scintag theta-2-theta goniometer and X-ray tube with a copper target. Separate clay samples were also $\mathrm{KCl}$ saturated and heat treated to $400^{\circ} \mathrm{C}$ and others were $\mathrm{MgCl}_{2}$ saturated and solvated with ethylene glycol to identify expanding clay minerals. Jade 5.1 software was used to suggest mineral matches for each XRD pattern.

Soil $\mathrm{pH}$ was measured in a 1:2 weight to volume solution of $0.01 \mathrm{M}$ $\mathrm{CaCl}_{2}$. Cation exchange capacities of sterile and non-sterile soils as well as $\mathrm{H}_{2} \mathrm{O}_{2}$-treated soils were measured in duplicate after saturation with $0.5 \mathrm{M} \mathrm{MgCl}_{2}$. Entrained salts were removed by rinsing with distilled water. Surface bound $\mathrm{Mg}$ was measured by inductively coupled plasma-mass spectrometry (ICP-MS) following sequential rinses using $0.5 \mathrm{M} \mathrm{CaCl}_{2}$. Total organic carbon was determined using a LECO analyzer. Soil NOM was analyzed by UV-Vis spectroscopy following extraction in $0.01 \mathrm{M} \mathrm{CaCl}_{2}$. Non-crystalline iron phases were quantified by ammonium oxalate in the dark (AOD) extractions (Jackson et al., 1986).

\subsection{Uranium batch sorption experiments}

Batch sorption experiments were completed using sterile and nonsterile unaltered soils and pre-treated soils in polypropylene Oak Ridge tubes. Experiments were completed at room temperature in a reciprocating shaker using a solid/solution ratio of $20 \mathrm{~g} / \mathrm{L}$. Experiments were conducted at constant ionic strength $\left(0.1 \mathrm{M} \mathrm{NaNO}_{3}\right)$ and buffered to a constant $\mathrm{pH}$ of 7.6 using $25 \mathrm{mmol} / \mathrm{L}$ HEPES. Preliminary experiments were conducted to determine the duration required to reach adsorption equilibrium $(\sim 48 \mathrm{~h})$. After the reactions were completed, suspensions were removed from the shaker and centrifuged ( $1500 \mathrm{rpm}$ for $15 \mathrm{~min}$ ) and the supernatants were sampled for $\mathrm{pH}$ and $\mathrm{U}(\mathrm{VI})$ measurements. $\mathrm{U}(\mathrm{VI})$ concentrations were measured 
Table 1

Select soil properties of non-sterile, autoclaved, and irradiated sediments

\begin{tabular}{lcllll}
\hline Sample & $\mathrm{pH}$ & $\begin{array}{l}\mathrm{CEC} \\
\left(\mathrm{cmol}_{\mathrm{c}} / \mathrm{kg}\right)\end{array}$ & $\begin{array}{l}\text { CEC (NOM removed) } \\
\left(\mathrm{cmol}_{\mathrm{c}} / \mathrm{kg}\right)\end{array}$ & $\begin{array}{l}\text { UV Absorbance @ } \\
254 \mathrm{~nm}\end{array}$ & $\begin{array}{l}\text { Cells/g } \\
\text { soil }\end{array}$ \\
\hline Non-sterile soil & 7.6 & $39 \pm 3$ & $12 \pm .7$ & 1.16 & 21,000 \\
Autoclaved soil & 7.6 & $39 \pm .3$ & Not measured & .98 & 0 \\
Irradiated soil & 7.5 & $31 \pm .1$ & $19 \pm 4$ & .91 & 0 \\
\hline
\end{tabular}

using a kinetic phosphorescence analyzer (KPA) and inductively coupled plasma-mass spectrometry (ICP-MS). The total amount of $U$ (VI) removed from solution was calculated from the difference between the initial and final aqueous concentrations. Batch experiments were completed in duplicate with initial $\mathrm{U}(\mathrm{VI})$ concentrations ranging from 0.1 to $10 \mathrm{ppm}$. Anaerobic batch experiments were completed in an anaerobic glove bag with $\mathrm{N}_{2} / \mathrm{H}_{2}$ atmosphere and the $\mathrm{O}_{2}$ concentration in the bag was monitored at $0 \mathrm{ppm}$ for the duration of the experiment.

Aerobic batch experiments were also completed on separate size fractions of the sediment. The two size fractions used were $>50 \mu \mathrm{m}$ (sand fraction) and $<2 \mu \mathrm{m}$ (clay fraction). Experiments were allowed to react for $300 \mathrm{~h}$ using $10 \mathrm{mmol} / \mathrm{L}$ HEPES buffer and initial U(VI) concentrations between 0.1 and $4 \mathrm{ppm}$. X-ray absorption near-edge structure (XANES) spectroscopy was performed on select samples from various batch reactions to determine the valence state of uranium on the solid phase.

\subsection{Mössbauer spectroscopy}

${ }^{57} \mathrm{Fe}$ Mössbauer spectroscopy was used to characterize Fe-mineralogy and to identify any changes in the valence state of Fe caused by exposure to $\gamma$-irradiation. Mössbauer spectroscopy was performed on 6 samples including 2 non-sterile untreated soil samples, 2 samples which had been irradiated for $40 \mathrm{~h}$, one non-sterile $\mathrm{H}_{2} \mathrm{O}_{2}$ plus DCBtreated sample, and one $\mathrm{H}_{2} \mathrm{O}_{2}$ plus DCB-treated irradiated soil. Approximately $100 \mathrm{mg}$ of air-dried sample was used for each analysis. Spectra were collected at room temperature (RT) and at $12 \mathrm{~K}$. Details of Mössbauer instrumentation, sample preparation procedure, and model (Voigt-based method (Rancourt and Ping, 1991)) employed for fitting were reported by Kukkadapu et al. (Kukkadapu et al., 2004; Kukkadapu et al., 2006). Briefly, spectra were collected using a ${ }^{57} \mathrm{Co} / \mathrm{Rh}$ source with an initial activity of $50 \mathrm{mCi}$ in the constantacceleration mode $(23 \mathrm{~Hz})$ with metallic Fe-foil (25-micron) at RT used for calibration. The coefficients of variation of the spectral areas of the individual sites generally varied by less than $1 \%$ of the fitted value.

\section{Results and discussion}

\subsection{Soil analysis}

The soil consisted mainly of quartz with some albite and illite, interlayered illite/smectite, and minor amounts of kaolinite. The Fe content of the sediment was approximately 4.0 weight \% and less than 0.1 weight \% occurred in non-crystalline Fe phases. The total organic carbon concentration of the soil is low (0.1\%). XRD analyses did not detect any changes in major mineralogy, including clay mineralogy, due to sterilization.

The results of selected soil analyses are presented in Table 1. Soil $\mathrm{pH}$ decreased slightly from about 7.6 to about 7.5 after $\gamma$-sterilization and no changes occurred due to autoclaving. Sediment samples that were exposed to $\gamma$-rays displayed lower CEC values compared to those that were not sterilized or were sterilized by autoclave (Table 1). CEC was also determined using samples which were $\mathrm{H}_{2} \mathrm{O}_{2}$ treated to determine the relative contribution of NOM to cation exchange. After NOM removal, CEC decreased in both the sterile and non-sterile samples. However, CEC decreased more significantly in the non-sterile sediments compared to the $\gamma$-irradiated sediments. These results suggested that exposure to irradiation may have caused a decrease in the CEC of the organic fraction of the sediments and an overall increase in the CEC of the mineral fraction of the soil.

To investigate the possible breakdown of NOM by $\gamma$-irradiation, organic matter from sterile and non-sterile samples was examined by UV-Vis spectroscopy after extraction by $0.01 \mathrm{M} \mathrm{CaCl}_{2}$ (Schaumann, 2000). Absorption was measured at a wavelength of $254 \mathrm{~nm}$ (Table 1) which correlates to the total organic carbon component of aqueous samples (Deflandre and Gagne, 2001). Specifically, decreased UV
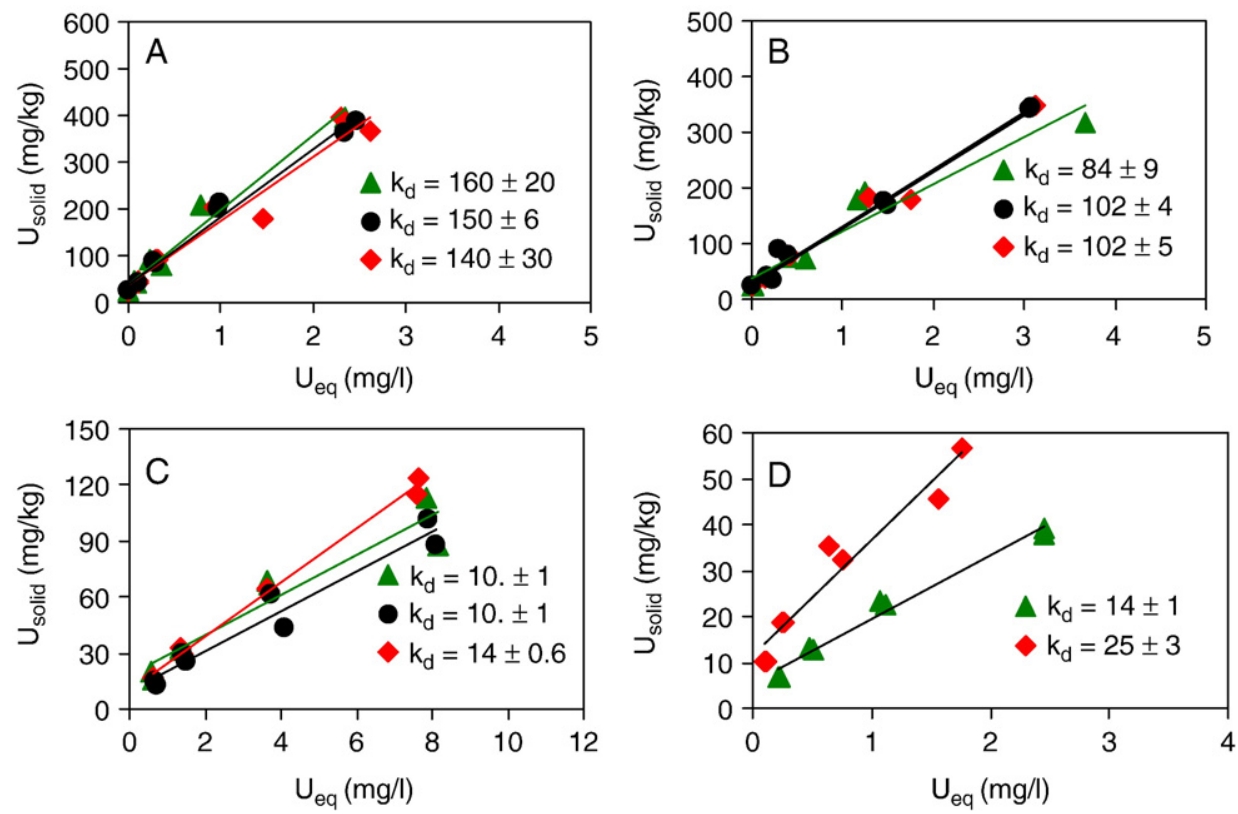

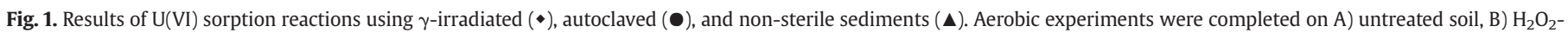
treated soil, and $\mathrm{C}$ ) both $\mathrm{H}_{2} \mathrm{O}_{2}$ and DCB-treated soil. Anaerobic batch experiments were completed on D) untreated soils. $k_{\mathrm{d}}$ values were calculated from Langmuir isotherms. 


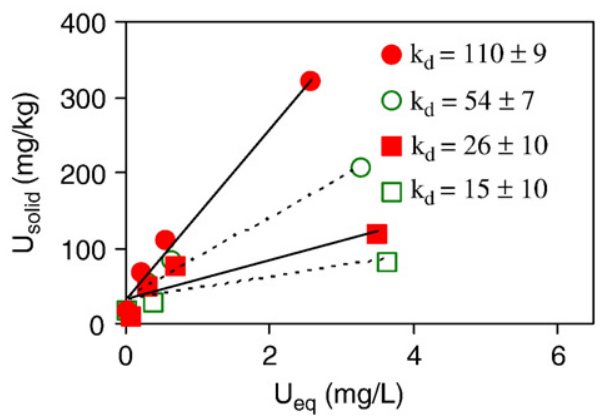

Fig. 2. Results of batch reactions using physically separated clay (•) and sand (•) size fractions that were not chemically treated. Closed symbols represent irradiated samples and open symbols represent non-sterile samples. Autoclaved samples were not used in this experiment.

absorption at $254 \mathrm{~nm}$ indicated fewer carbon-carbon double bonds (Ghosh and Schnitzer, 1979; Traina et al., 1990; Pushkareva et al., 2002) and suggested that large NOM molecules were broken into smaller fragments after exposure to ionizing radiation. The breakdown of organic matter may cause a release of $\mathrm{H}^{+}$which would slightly lower the irradiated soil $\mathrm{pH}$ as observed in this study. Breakdown of NOM may have also occurred in autoclaved soil but to a lesser extent. A more detailed study of the NOM is needed to fully understand the effects of $\gamma$-sterilization on these samples, but these preliminary results suggest that the breakdown of NOM may cause the decrease in CEC that was measured in untreated but irradiated sediment samples. In samples that were treated to chemically remove the NOM, a significant increase in CEC is measured after $\gamma$-irradiation.

\subsection{Sterilization efficacy}

Viable cell counts were remarkably different in the non-sterilized clay-rich weathered limestone compared to the shale fractions. Many more microorganisms were present in the weathered clay fraction $\left(2 \times 10^{5}\right.$ cells $\mathrm{g}^{-1}$ soil) compared to the sand fraction $\left(\sim 2 \times 10^{2}{\text { cells } \mathrm{g}^{-1}}^{-1}\right.$ soil). After irradiation there were no viable cells counted in any sample and our success rate was at least $99.99 \%$. Although no viable cells were identified in this study after sterilization, it is documented that $\mathrm{Ba}$ cillus subtilus has survived larger doses of irradiation (Romanovskaia et al., 2002). Sterilization by three successive autoclave periods was equally efficient in destroying viable cells in these soils.

\section{3. $U(V I)$ sorption}

Results from the $\mathrm{U}(\mathrm{VI})$ batch sorption experiments are shown in Figs. 1 and 2. Adsorption constants were calculated using the Langmuir isotherm. In untreated sediment samples, values of $k_{\mathrm{d}}$ did not vary appreciably due to sterilization (Fig. 1A) indicating that biological activity did not play a significant role in $U(V I)$ sorption or reduction in these sediments. The large error values likely reflect natural heterogeneity in the sediment samples. As expected, after removal of soil NOM, all $k_{\mathrm{d}}$ values decreased significantly (Fig. 1B). As well, treatment to remove both NOM and iron (hydr)oxide minerals caused the $k_{\mathrm{d}}$ value to decrease by approximately $90 \%$ (Fig. 1C). These results indicated that sorption of $\mathrm{U}(\mathrm{VI})$ was largely controlled by the organic matter and iron oxide minerals present in the sediment, which is consistent with previous studies on similar sediments (Yanase et al., 1991; Payne et al., 1994; Lenhart et al., 2000; Roh et al., 2000; Logue et al., 2004; Liu et al., 2005; Stubbs et al., 2006).

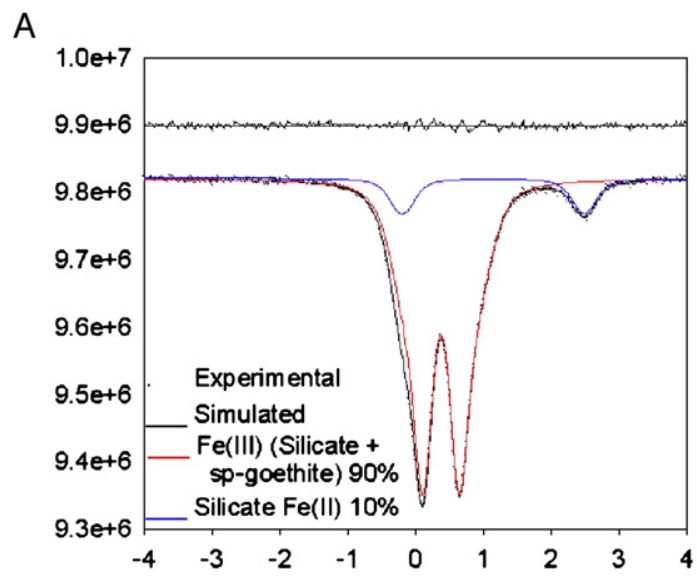

B

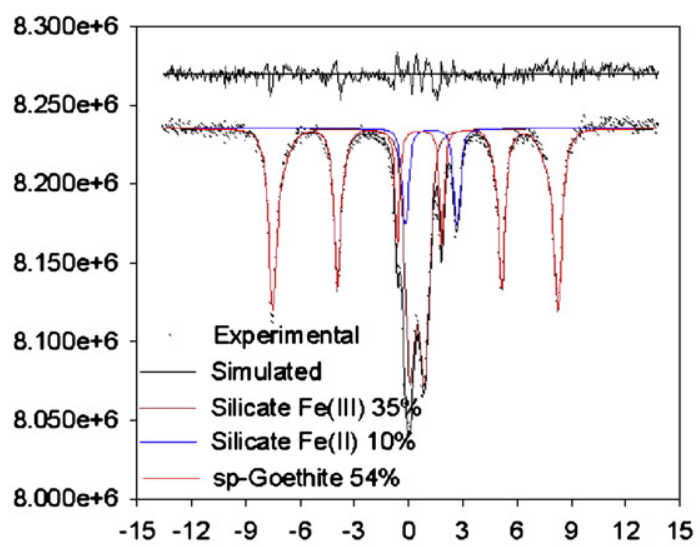

C

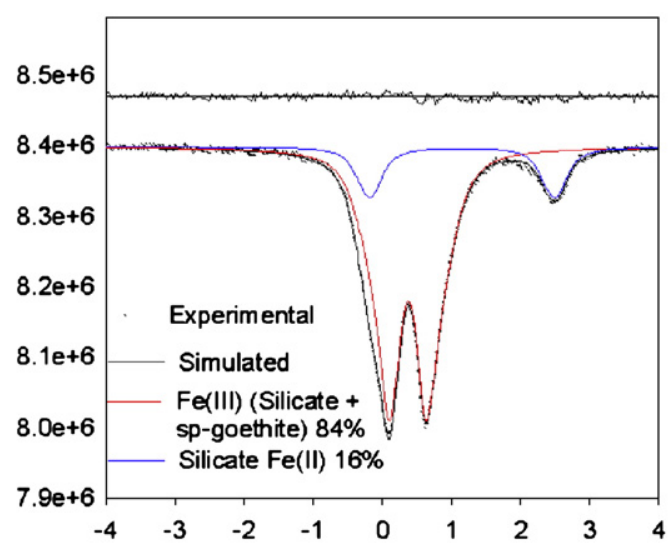

D

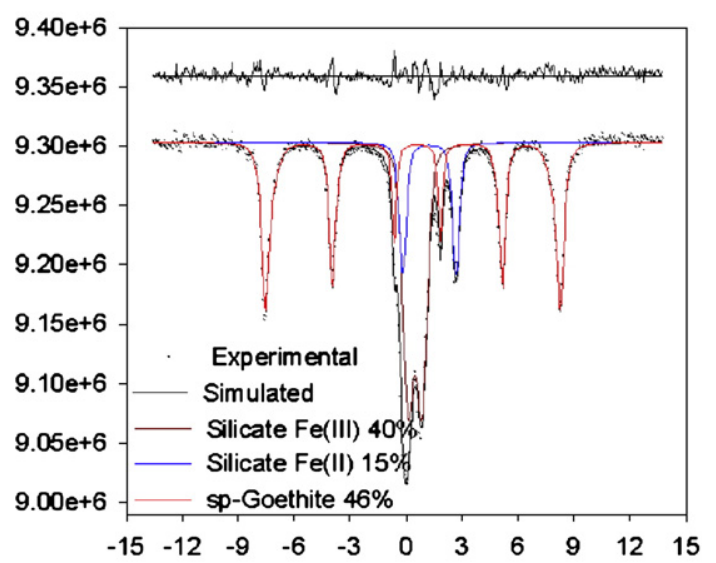

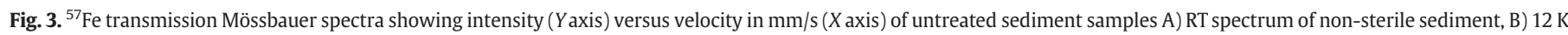
spectrum of non-sterile sediment, C) RT spectrum of irradiated sediment and D) $12 \mathrm{~K}$ spectrum of irradiated sediment. Duplicate samples not shown. 
XANES analysis was completed on selected samples and revealed that uranium existed solely as sorbed $\mathrm{U}(\mathrm{VI})$ and that no measurable amount of reduced U(IV) was produced (spectra not shown). However, reduced $\mathrm{U}(\mathrm{IV})$ may have been present in concentrations below the detection limit $(\sim 10 \%)$.

Uranium sorption data collected from anaerobic experiments showed significant effects associated with sterilization (Fig. 1D). Significantly more $\mathrm{U}(\mathrm{VI})$ was associated with untreated sediments that were sterilized by $\gamma$-irradiation compared to non-sterile samples. Values of $k_{\mathrm{d}}$ associated with $\gamma$-irradiated and non-sterile sediments were $25 \pm 3$ and $14 \pm 1$, respectively. Because anaerobic $k_{\mathrm{d}}$ values were significantly smaller than $k_{\mathrm{d}}$ values measured under aerobic conditions, sorption experiments were not completed using samples treated with $\mathrm{H}_{2} \mathrm{O}_{2}$ and $\mathrm{H}_{2} \mathrm{O}_{2}$ plus DCB.

Sterile and non-sterile sediment samples that were treated with $\mathrm{H}_{2} \mathrm{O}_{2}$ to remove the NOM displayed statistically different $\mathrm{U}(\mathrm{VI})$ sorption behavior; the autoclaved and $\gamma$-irradiated sediments were more effective sorbents of $\mathrm{U}(\mathrm{VI})$. Also, $k_{\mathrm{d}}$ values indicated that more $\mathrm{U}$ (VI) sorption occurred on $\gamma$-irradiated samples treated by both DCB and $\mathrm{H}_{2} \mathrm{O}_{2}$ compared to autoclaved and non-sterile samples. These results suggested that irradiation may have caused a change in the chemistry of the soil that increased the sorption capacity, which is in agreement with CEC measurements. Likely, a change in the physicochemical properties of the mineral fraction occurred which made the sediment samples better $\mathrm{U}(\mathrm{VI})$ sorbents. Possibly, iron in the clay and oxide minerals is reduced during the sterilization and increases the CEC of the sediments.

Less $\mathrm{U}(\mathrm{VI})$ was associated with NOM in sterilized sediment samples compared to the non-sterile sediment ( $32 \%$ and $44 \%$, respectively) as determined by the change in $k_{\mathrm{d}}$ values following $\mathrm{H}_{2} \mathrm{O}_{2}$ treatment (see Fig. 1A-B). These results were consistent with UV-Vis spectra which indicated that NOM was degraded by both sterilization methods. Differences in the $k_{\mathrm{d}}$ values of DCB-treated sediments also suggested that $\gamma$-irradiation may have affected the clay mineral reactivity. Autoclaved sediment samples that were either untreated or $\mathrm{H}_{2} \mathrm{O}_{2}$ treated are not statistically different from irradiated samples. However, there are significant differences in the autoclaved and irradiated $k_{\mathrm{d}}$ values of $\mathrm{H}_{2} \mathrm{O}_{2}$ plus $\mathrm{DCB}$-treated sediments suggesting that irradiation also caused changes in the sediment silicate minerals, possibly reduction of trivalent iron as determined in previous studies (Gournis et al., 2000; Plotze et al., 2003).

Uranium sorption was also measured on physically separated sand and clay size fractions (Fig. 2). Significantly greater sorption occurred onto the clay-sized fraction compared to the sand, which is likely due to increased surface area. The $\gamma$-irradiated sediments, again, sorbed significantly more $\mathrm{U}(\mathrm{VI})$ compared to the non-sterile samples, and the effect of irradiation on the clay-sized samples was much greater compared to the courser size fraction.

\subsection{Mössbauer spectroscopy}

To test the hypothesis that iron-bearing minerals were chemically altered by $\gamma$-sterilization, ${ }^{57} \mathrm{Fe}$-Mössbauer spectroscopy was performed on non-sterile and $\gamma$-irradiated sediment samples (both untreated and $\mathrm{H}_{2} \mathrm{O}_{2}$ plus DCB-treated). Since the effect of $\gamma$ sterilization on the CEC and uranium sorption was greater than the effect of autoclaving (see Table 1 and Fig. 1C), only irradiated samples were analyzed. Mineral assignment was based on published work that was completed on sediments obtained from the same general locality (Kukkadapu et al., 2006; Komlos et al., 2007). Duplicate samples were analyzed with consistent results. Mössbauer spectra convincingly showed that sterilization by $\gamma$-irradiation induced changes in the oxidation state of iron in the sediment (Fig. 3), which was clearly evident from room temperature (RT) spectra (compare Fig. 3A and C). $\mathrm{Fe}(\mathrm{II})$ content increased to $16 \%$ (18\% in duplicate sample) from the initial $10 \%$. At this measurement temperature, silicate $\mathrm{Fe}(\mathrm{III})$ (e.g.,
A

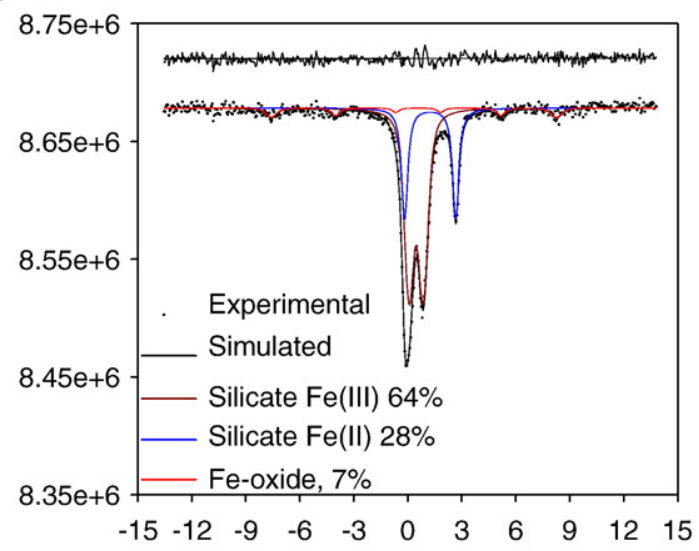

B

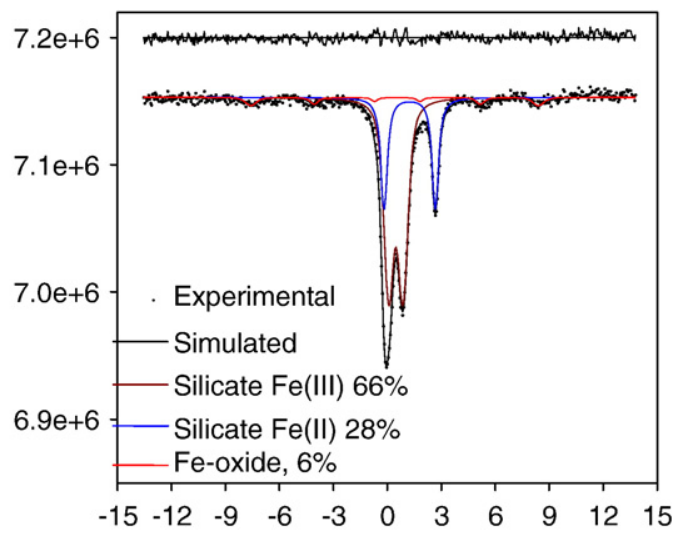

Fig. 4. ${ }^{57} \mathrm{Fe}$ transmission Mössbauer spectra showing intensity ( $Y$ axis) versus velocity in $\mathrm{mm} / \mathrm{s}$ ( $\mathrm{X}$ axis) of $\mathrm{H}_{2} \mathrm{O}_{2}$ plus DCB-treated sediment samples $\mathrm{A}$ ) $12 \mathrm{~K}$ spectrum of nonsterile sample and $\mathrm{B}$ ) $12 \mathrm{~K}$ spectrum of irradiated sample.

illite) and small particle/Al-substituted goethite $\mathrm{Fe}(\mathrm{III})$ peaks are indistinguishable from each other (Kukkadapu et al., 2006). At lower temperatures (below $77 \mathrm{~K}$ ) however, these peaks are distinct (Murad and Cashion, 2004), which is evident from the $12 \mathrm{~K}$ spectrum (Fig. 3B and $\mathrm{D}$ ). The decrease in goethite content (by $6 \%$ and $8 \%$ in the duplicate samples) after irradiation closely corresponded to the increase in Fe(II) measured in both irradiated samples and suggested that goethite is being principally reduced. Measurements at or near liquid $\mathrm{He}$ temperature $(4.2 \mathrm{~K})$ are needed to resolve silicate $\mathrm{Fe}(\mathrm{II})$ from other $\mathrm{Fe}(\mathrm{II})$ species. In the present study $4.2 \mathrm{~K}$ measurements were not completed since the changes in silicate $\mathrm{Fe}(\mathrm{II})$ content appeared to be within modeling errors. Similar spectra of non-sterile and $\gamma$-irradiated DCB-treated sediments (samples which should contain mostly iron in clay minerals, see Fig. 4) display no measurable $\gamma$-induced iron reduction. These results suggest that most of the $\mathrm{Fe}(\mathrm{II})$ in sterilized samples was produced by reduction of $\mathrm{Fe}(\mathrm{III})$ in goethite, possibly caused by exposure to $\gamma$-irradiation. It is possible that the DCB treatment used to remove iron oxide minerals from our sediment samples partially reduced any iron associated with the silicate minerals, masking any effects of the $\gamma$-irradiation in Fig. 4 (Kukkadapu et al., 2006).

The iron reduction associated with irradiation of goethite is possibly due to the formation of .H radicals due to radiolysis of mineral surface water molecules (Gournis et al., 2000)

$\mathrm{Fe}^{3+}+\mathrm{H}^{\mathrm{U}} \leftrightarrow \mathrm{Fe}^{2+}+\mathrm{H}^{+}$

Although the sediments were air-dried prior to irradiation some atmospheric or surface bound water molecules would have remained 
with the sample. Irradiation-induced reduction of iron in illite and smectite minerals may have occurred to a lesser extent, though Mössbauer data from this study do not report measurable iron reduction in the clay-sized fraction of the sediment. Previous studies of the effects of much higher doses of $\gamma$-irradiation have found a partial reduction of $\mathrm{Fe}(\mathrm{III})$ to $\mathrm{Fe}(\mathrm{II})$ in various clay minerals (Gournis et al., 2000; Plotze et al., 2003). The interlayer water molecules associated with clay mineral structure would serve as source of hydrogen radicals for iron reduction. Uranium sorption data onto claysized sediment fractions hint that clay minerals may be significantly altered by sterilization (Fig. 2). However, it is also possible that colloidal iron (hydr)oxide minerals are present in higher concentrations in the finer sediment material compared to the coarser fraction. Although Mössbauer data do not indicate any measurable $\gamma$-induced iron reduction in the $\mathrm{H}_{2} \mathrm{O}_{2}$ and DCB-treated sediment, reduced iron may occur at levels below the detection limit.

Increased association of uranium with $\gamma$-sterilized sediment samples may be due to several mechanisms. It is possible that hexavalent uranium may have been reduced to U(IV) by $\gamma$-reduced Fe (II) at concentrations not detectable by XANES (detection limit=10\%). Also, because $\mathrm{U}(\mathrm{VI})$ adsorption is very dependent on soil $\mathrm{pH}$ and $\mathrm{U}(\mathrm{VI})$ exhibits a reverse adsorption edge in the relatively narrow $\mathrm{pH}$ range of $7.5-8$, the very small decrease in $\mathrm{pH}$ measured after irradiation may have increased the sorption capacity of the sterilized soils (Barnett et al., 2000; Barnett et al., 2002). Alternatively, it is possible that sterilization by irradiation caused changes in the sorption capacity of the soil unrelated to the drop in $\mathrm{pH}$, as is supported by CEC data. Because $k_{\mathrm{d}}$ values differ significantly in non-sterile versus irradiated samples treated with $\mathrm{H}_{2} \mathrm{O}_{2}$ and $\mathrm{H}_{2} \mathrm{O}_{2}$ plus $\mathrm{DCB}$, it is possible that the $\gamma$ induced reduction of $\mathrm{Fe}(\mathrm{III})$-bearing oxide and/or silicate minerals increased $\mathrm{U}(\mathrm{VI})$ sorption onto the solid sample. The increased $\mathrm{Fe}(\mathrm{II}) / \mathrm{Fe}$ (III) ratio of $\gamma$-sterilized sediments may slightly decrease the surface charge of iron-bearing minerals making the solids more conducive to sorption of any cationic $\mathrm{U}(\mathrm{VI})$ species that may be present in the system (i.e. $\left.\left(\mathrm{UO}_{2}\right)_{3}(\mathrm{OH})_{5}^{+}\right)$(Barnett et al., 2000).

The irradiation dose investigated in this research $(20 \mathrm{kGy})$ is comparable to the ionizing radiation emitted by a nuclear waste container over the course of an entire year. A previous study investigating the geomicrobiology of sediments in the vicinity of high-level nuclear waste reported very few bacterial isolates capable of surviving the same dosage of radiation (Fredrickson et al., 2004). It would also be interesting to determine if the physico-chemical properties of that soil were altered due to irradiation. Certainly, $\gamma$ irradiation is an efficient sterilization method with many benefits over autoclaving, but its use in geochemical studies of soil reactivity is questionable. Certainly, the results presented in this study show that $\gamma$-irradiation affects more than just the organic and clay mineral fractions of complex soils, as previously reported.

The results of this study on natural soils warrant further research on the effects of small to moderate doses of $\gamma$-irradiation on complex sediment systems. The effects of $\gamma$-irradiation on the reduction of Fe (III) in separate iron oxide and iron silicate minerals could be investigated to gain a better understanding of the reduction process. The potential changes in sediment sorption capacity and mineral oxidation state associated with ionizing radiation in the vicinity of nuclear waste containers would be of great interest to those studying contaminant migration and geochemical reactions associated with metal mobilization and immobilization.

\section{Acknowledgements}

This research was sponsored by the Natural and Accelerated Bioremediation Research (NABIR) program of the U.S. Department of Energy (DOE). Oak Ridge National Laboratory is managed by UTBattelle, LLC, for the U.S. Department of Energy under contract DEAC05-000R2272. Mössbauer spectroscopy was performed in the
Environmental Molecular Sciences Laboratory, a national scientific user facility sponsored by the Department of Energy's Office of Biological and Environmental Research and located at Pacific Northwest National Laboratory. A portion of this work was conducted at Stanford Synchrotron Radiation Laboratory, a national user facility operated by Stanford University on behalf of the U.S. Department of Energy, Office of Basic Energy Sciences. The SSRL Structural Molecular Biology Program is supported by the Department of Energy, Office of Biological and Environmental Research, and by the National Institutes of Health. Tonia Mehlhorn, Xiangping Yin, and Deanne Brice assisted in sample and data collection. T. Phelps and S. Brooks provided helpful discussions in the preparation of this manuscript.

\section{References}

Allen, C.C., et al., 1999. Effects of sterilizing doses of gamma radiation on Mars analog rocks and minerals. Journal of Geophysical Research-Planets 104 (E11), 27043-27066.

Apitz, S.E., et al., 1999. The development of a sterile, PAH-spiked, aged marine sediment for biodegradation experiments: chemical results. Organic Geochemistry 30 (8B) 891-900.

Barnett, M.O., Jardine, P.M., Brooks, S.C., Selim, H.M., 2000. Adsorption and transport of uranium(VI) in subsurface media. Soil Science Society of America Journal 64 (3), 908-917.

Barnett, M.O., Jardine, P.M., Brooks, S.C., 2002. U(VI) adsorption to heterogeneous subsurface media: application of a surface complexation model. Environmental Science \& Technology 36 (5), 937-942.

Bowen, G.D., Rovira, A.D., 1961. Plant growth in irradiated soil. Nature 191, 936-937.

Bunzl, K., Schimmack, W., 1988. Effect of microbial biomass reduction by gammairradiation on the sorption of Cs-137, Sr-85, Ce-139, Co-57, Cd-109, Zn-65, Ru-103, Tc-95 $\mathrm{m}$ and I-131 by Soils. Radiation and Environmental Biophysics 27 (2), $165-176$.

Deflandre, B., Gagne, J.P., 2001. Estimation of dissolved organic carbon (DOC) concentrations in nanoliter samples using UV spectroscopy. Water Research 35 (13), 3057-3062.

Fredrickson, J.K., et al., 2004. Geomicrobiology of high-level nuclear waste-contaminated vadose sediments at the Hanford Site, Washington State. Applied and Environmental Microbiology 70 (7), 4230-4241.

Getenga, Z.M., Dorfler, U., Reiner, S., Sabine, K., 2004. Determination of a suitable sterilization method for soil in isoproturon biodegradation studies. Bulletin of Environmental Contamination and Toxicology 72 (2), 415-421.

Ghosh, K., Schnitzer, M., 1979. UV and visible absorption spectroscopic investigations in relation to macromolecular characteristics of humic substances. Journal of Soil Science 30 (4), 735-745.

Golde, H.M., Crosby, M.P., Lovell, C.R., Stancyk, S.E., 1994. Reduction of marine sediment oxygen uptake: pre-treatment for the determination of infaunal respiration rates. Marine Ecology Progress Series 111, 203-207.

Gournis, D., Mantaka-Marketou, A., Karakassides, M., Petridis, D., 2000. Effect of gamma- irradiation on clays and organoclays: a Mossbauer and XRD study. Physics and Chemistry of Minerals 27 (7), 514-521.

Gournis, D., Mantaka-Marketou, A.E., Karakassides, M.A., Petridis, D., 2001. Ionizing radiation-induced defects in smectite clays. Physics and Chemistry of Minerals 28, 285-290.

Herbert, R.B., et al., 2005. Quantification of abiotic reaction rates in mine tailings: evaluation of treatment methods for eliminating iron- and sulfur-oxidizing bacteria. Environmental Science \& Technology 39 (3), 770-777.

Jackson, M.L., Lim, C.H., Zelazny, L.W., 1986. Oxides, hydroxides, and aluminosilicates. In: Klute, A. (Ed.), Methods of soil analysis. Part 1. ASA and SSSA, Madison, WI, pp. 113-119.

Jardine, P.M., Wilson, G.V., Luxmoore, R.J., 1988. Modeling the transport of inorganic ions through undisturbed soil columns from 2 contrasting watersheds. Soil Science Society of America Journal 52, (1252-1259).

Jardine, P.M., Wilson, G.V., Luxmoore, R.J. and Gwo, J.P., 2001. Conceptual Model of Vadose- Zone Transport in Fractured Weathered Shales National Research Council. In: N.R.C. U.S. National Committee for Rock Mechanics (Editor), Conceptual Models of Flow and Transport in the Fractured Vadose Zone. National Academy Press, Washington, D.C., pp. 87-114.

Klute, A. (Ed.), 1986. Methods of Soil Analysis: Physical and Mineralogical Methods. Soil Science Society of America, Inc., Madison, Wisconsin. 1188 pp.

Komlos, J., Kukkadapu, R.K., Zachara, J.M. and Jaffe, P., 2007. Biostimulation of iron reduction and subsequent oxidation of seiment containing Fe-silicates and $\mathrm{Fe}$ oxides: Effect of redox cycling on Fe(III) bioreduction. Water Research, in print.

Kreller, D.I., Turner, B.F., Namjesnik-Dejanovic, K., Maurice, P.A., 2005. Comparison of the effects of sonolysis and gamma-radiolysis on dissolved organic matter Environmental Science \& Technology 39 (24), 9732-9737.

Kukkadapu, R., Zachara, J., Fredrickson, J., Kennedy, D., 2004. Biotransformation of twoline silica-ferrihydrite by a dissimilatory $\mathrm{Fe}(\mathrm{III})$-reducing bacterium: formation of carbonate green rust in the presence of phosphate. Geochimica et Cosmochimica Acta 68 (13), 2799-2814.

Kukkadapu, R.K., et al., 2006. Reductive biotransformation of Fe in shale-limestone saprolite containing $\mathrm{Fe}(\mathrm{III})$ oxides and $\mathrm{Fe}(\mathrm{II}) / \mathrm{Fe}(\mathrm{III})$ phyllosilicates. Geochimica et Cosmochimica Acta 70 (14), 3662-3676. 
Lenhart, J.J., Cabaniss, S.E., MacCarthy, P., Honeyman, B.D., 2000. Uranium(VI) complexation with citric, humic and fulvic acids. Radiochimica Acta 88 (6), 345-353.

Liu, C.X., et al., 2005. Influence of sediment bioreduction and reoxidation on uranium sorption. Environmental Science \& Technology 39 (11), 4125-4133.

Logue, B.A., Smith, R.W., Westall, J.C., 2004. U(VI) adsorption on natural iron-coated sands: comparison of approaches for modeling adsorption on heterogeneous environmental materials. Applied Geochemistry 19 (12), 1937-1951.

Lotrario, J.B., et al., 1995. Effects of sterilization methods on the physical characteristics of soil-implications for sorption isotherm analyses. Bulletin of Environmental Contamination and Toxicology 54 (5), 668-675.

Manning, A.R., Radloff, K.A., Mailloux, B., van Green, A., 2006. Effective sterilization techniques for long term incubations of Bangladesh aquifer sands. Geological Society of America Annual Meeting, Philadelphia.

McLaren, A.D., 1969. Radiation as a technique in soil biology and biochemistry. Soil Biology \& Biochemistry 1, 63-73.

McNamara, N., Black, H., Beresford, N., Parekh, N., 2003. Effects of acute gamma irradiation on chemical, physical and biological properties of soils. Applied Soil Ecology 24 (2), 117-132.

Murad, E., Cashion, J., 2004. Mossbauer spectroscopy of environmental materials and their industrial utilization. Academic Publishers.

Negron, A., Ramos, S., Blumenfeld, A.L., Pacheco, G., Fripiat, J.J., 2002. On the structural stability of montmorillonite submitted to heavy g-irradiation. Clays and Clay Minerals 50 (1), 35-37.

Payne, T.E., Davis, J.A., Waite, T.D., 1994. Uranium retention by weathered schists - the role of iron minerals. Radiochimica Acta 66-7, 297-303.

Plotze, M., Kahr, G., Stengele, R.H., 2003. Alteration of clay minerals - gammairradiation effects on physicochemical properties. Applied Clay Science 23 (1-4), 195-202.

Pushkareva, R., et al., 2002. Irradiation effect on physico-chemical properties of clay minerals. Applied Clay Science 21 (1-2), 117-123.
Rancourt, D., Ping, J., 1991. Voigt-based methods for arbitrary-shape static hyperfine parameter distributions in Mössbauer-spectroscopy. Nuclear Instruments; Methods in Physics Research Section B-Beam Interactions with Materials and Atoms 58 (1), 85-97.

Roh, Y., Lee, S.R., Choi, S.K., Elless, M.P., Lee, S.Y., 2000. Physicochemical and mineralogical characterization of uranium-contaminated soils. Soil \& Sediment Contamination 9 (5), 463-486.

Romanovskaia, V.A. et al, 2002. The effect of gamma-radiation and desiccation on the viability of the soil bacteria isolated from the alienated zone around the Chernobyl Nuclear Power Plant. Mikrobiologiia 71 (5), 705-712.

Schaumann, G., 2000. Effect of $\mathrm{CaCl}_{2}$ on the kinetics of dissolved organic matter release from a sandy soil. Journal of Plant Nutrition and Soil Science 163, 523-529.

Stubbs, J.E., Elbert, D.C., Veblen, D.R., Zhu, C., 2006. Electron microbeam investigation of uranium-contaminated soils from Oak Ridge, TN, USA. Environmental Science \& Technology 40 (7), 2108-2113.

Traina, S.J., Novak, J., Smeck, N.E., 1990. An ultraviolet absorbance method of estimating the percent aromatic carbon content of humic acids. Journal of Environmental Quality 19 (1), 151-153.

Trevors, J., 1996. Sterilization and inhibition of microbial activity in soil. Journal of Microbiological Methods 26 (1-2), 53-59.

Tuominen, L., Kairesalo, T., Hartikainen, H., 1994. Comparison of methods for inhibiting bacterial activity. Sediment Applied and Environmental Microbiology 60 (9), 3454-3457.

Wolf, D.C., Dao, T.H., Scott, H.D., Lavy, T.L., 1989. Influence of sterilization methods on selected microbiological, physical, and chemical properties. Journal of Environmental Quality 18, 39-44.

Yanase, N., Nightingale, T., Payne, T., Duerden, P., 1991. Uranium distribution in mineral phases of rock by sequential extraction procedure. Radiochimica Acta 52-3, 387-393. 